\title{
Perceptions of destination image and effects on college football fans: A case study of conference realignment
}

\author{
Cheryl Rode \\ College of Hospitality and Tourism Management, \\ Niagara University, United States \\ School of Hospitality and Tourism Management, \\ Western Carolina University, United States \\ Angela Sebby \\ College of Hospitality and Tourism Management, \\ Niagara University, United States \\ School of Hospitality and Tourism Management, \\ Western Carolina University, United States \\ Kenneth Jordan \\ College of Hospitality and Tourism Management, \\ Niagara University, United States \\ School of Hospitality and Tourism Management, \\ Western Carolina University, United States
}

\begin{abstract}
Conference realignment among collegiate institutions in the United States has altered discussions from the traditional rivalries, standard television contracts, and typical super conferences. One area overlooked is the impact this may have on fans and their motivations to travel to the institutions' away-game opponents in the newly configured athletic conference. This case study examines the motivations of fans from one university that recently changed conference affiliations to travel to away games. An exploratory factor analysis revealed nine motivations to travel to an away game. The nine motivations present in this study are achievement, economic, escape, knowledge, group affiliation, social, aesthetic, eustress and family. Destination image was compared to the motivations of sport consumption to see if a correlation was present. Destinations that offer the appropriate infrastructure, relevant hospitality industry suppliers, and gregariousness present the opportunity to increase fan satisfaction and attendance. Conference realignments may continue to transpire, and forthcoming travel to away games will continue due to the motivations present to observe the fan's team compete and win. It will be essential for Convention and Visitor Bureaus and other tourism entities within cities to strategically partner with the local university to promote the destination area, in addition to the sporting event, to generate increased tourism from visitors and sports fans to the area.
\end{abstract}

Keywords: destination image, sport, college football, motivations, tourism

\section{INTRODUCTION}

College football has a wide-ranging basis of fans across the United States who traditionally fill historic stadiums on Saturdays in the fall, traveling many hours to both home and away games to support their favorite college teams. Attendance is declining at some universities, but overall attendance for NCAA Division I-FBS in 2016 totaled a record of more than 49 million fans, for an average of 42,631 per game-an increase over the previous five-year numbers [37]. This has resulted in athletic departments struggling to keep abreast of the "arms race" of major 
college athletics through the construction of new innovative stadiums or renovating current facilities $[40,53]$.

Previously, college football rivalries and conference match-ups were developed in the $20^{\text {th }}$ century; therefore a sense of comfort and a series of habits were established-especially related to how fans travel [33]. However, conference realignment has become increasingly prevalent in collegiate athletics. New rivalries are being established that require fans to experience novel away-game destinations, often at further distances. Both financial and competitive considerations have made way for a domino effect where institutions are shifting between conferences, ultimately transforming the makeup of college athletics.

These changes force both dedicated and casual fans to step outside their comfort zone by expanding their horizons and creating new experiences to follow their favorite teams [33]. An example of this fan evolution process is Texas A\&M University through its transition from a 1996 founding member of the Big 12 Conference to the Southeastern Conference in 2012. A\&M has a national fan base that has ranked in the top 10 in total fans [46]. The purpose of this case study is to identify the motivations of Texas A\&M fans to attend away games as a result of the realignment and the relationship between those motivations and destination image.

It is essential to understand if the destination image has a relationship with away-game attendance motivations. This will facilitate sport marketers and tourism officials to utilize destination image as a strategic tool to entice visiting fans to extend their visit to the area and recognize the copious leisure and entertainment options available. Consequently, extensive stays in the destination will augment the economic impact on the area. Specifically, this study (RQ1) identified the motivations for Texas A\&M fans to attend college football games and (RQ2) the relationship of motivations and destination image on travel to away college football games.

\section{Sports and Tourism}

\section{REVIEW OF LITERATURE}

Traveling to destinations is an integral part of the sport tourism enterprise. A $\$ 600$ billion industry spanning to thousands of sports and events worldwide, sport tourism is the fastest growing sector of worldwide tourism [58]. The destination itself becomes increasingly important as each locale with sport and tourism organizations endeavoring to increase attendance and consumer spending at events. Sports fans utilize the Internet and other forms of media to browse images of the locations; sharing experiences of places they have traveled to either recommend or discourage the destination as a place to travel $[24,49]$. The trust of sources, such as friends and family, is valuable and essential to consumers considering travel, especially with the emergence of online review sites like Trip Advisor, as recommendations have found to be a strong influence on decision making [39].

Additionally, websites and fan communities have been created specifically to review stadium experiences in every major sport. For example, StadiumJourney.com is a website dedicated to college football enthusiasts experience where fans who have attended events can submit reviews of all aspects of the stadium experience. This encompasses all tangible and intangible experiences, everything from concessions to ticket prices to the quality of the surrounding neighborhood and parking availability [49].

Sports fans become deeply attached to their teams and the players. Numerous fans will accompany them to events across the country besides following them on media outlets. Other demographics (i.e., gender, income, and age) and motivations (i.e., social, family, and team 
achievement) are influential fans factors as well as understanding what persuades or restricts fans from traveling to events [42]. Research has found geography-specifically, the distance traveled by fans to events and how isolated the location is in relation to other areas-as a constraining factor in hindering fans from traveling to sport and leisure events $[25,26]$. This fundamental driving force is why research into sport fan motivations to travel to away games is important. This case study provides insight into the motivations of Texas A\&M fans, their motivations to attend away games, and the relationship of those motivations with destination image.

\section{Sport Fan Motivation and Restraints}

The requirement to attract fans to sporting events is critical to the success of any sport organization and significantly impacts the destination area. Ticket sales are the primary source of revenue for sport organizations, while the fans' attendance at sporting venues attracts sponsors and advertising, another vital source of revenue. Numerous sport events necessitate spectators to travel more than 50 miles from their homes to attend and may even consist of overnight accommodations, the common definition of a tourist [59]. With increased tourists in the destination area, this results in additional revenue in the destination's hospitality and tourism industry: lodging, restaurants, and attractions. Chen \& Funk [7] state that sport tourism is a mix of both sports and tourism, instead of just attributes from one or the other, or even an unbalanced approach of sports and tourism. Additionally, the authors indicate "sport events play an important role in leveraging tourism for the host destination" (p. 239). Consequently, sport tourism has grown into a multi-billion dollar business.

Bridging the gap between attending a sporting event and actually traveling to the location has been explored in research to discover that the two areas have ample common motivations that lead to specific behaviors [27,47]. Understanding the desire for someone to travel to a destination with sport as the primary intention for travel is important for sport managers and marketers. As a result, this area has been studied extensively in regards to motivation to attend events. The study of sport fan motivation has been explored within many levels and categories of sport, including collegiate football. Through these studies, numerous scales have been generated to measure the various factors that contribute to fan motivations associated with attending a sporting event, and fan behavior [38,48,54]. Each scale provides a list of factors to help explain fan motivation in deciding to attend a sporting event. These scales include the Sport Fan Motivation Scale (SFMS) [54], the Motivation Scale for Sport Consumption (MSSC) [52] Sport Interest Inventory (SII) [18], and the SPEED Scale [19]. These scales have been used in a variety of sport settings with varying success in explaining motivation. Nonetheless, there are contextual differences in sporting events, which may impact the identified motivational factors among sports and across levels of competition, but the motivations identified by these scales are the generally accepted dimensions of fan motivation.

Specifically related to college football fandom, Kahle, Kambara, \& Rose [28] found three motivating factors for fan attendance. They were the desire for a unique, self-expressive experience, group affiliation, and the overall attachment or love of the game. The study also noted that the factor of group affiliation ultimately had a direct relationship with fan behaviors and attendance. In addition to the above-mentioned motivations, Wann [54] established additional motives through the Sport Fan Motivation Scale (SFMS). They include eustress, selfesteem, escape, entertainment, economic, aesthetics, group affiliation, and family.

The motive type eustress is considered a positive form of stress and energizes an individual $[54,57]$. The "good" stress is often sought by fans as it can arouse the senses and create an 
enjoyable experience. Self-esteem is the next motivation factor used to develop the SFMS. Fans feel a sense of accomplishment or achievement when their team is successful [54]. As fans enjoy this sense of success, they are more likely to increase their affiliation with the winning team. Even a sense of belonging achieved by participation in the experience of the event can affect the self-esteem of an individual [54].

Like most people, sports fans are busy with work, family and everyday stresses. The ability to find some type of escape or distraction from the conventional routine is another probable motivation factor to attend sporting events. This escape from the monotony of their lives allows sports fans to release their stresses through sport [54,57]. Getz [20] even goes so far to say "that escapism leads people to events for the generic benefits of entertainment and diversion, socializing, learning and doing something new, i.e., novelty seeking, and just plain getting away from it all" (p. 416). Entertainment-another motive-is closely linked to escape as the experience of a sporting event provides entertainment value to the spectator and fan [54]. In addition, money or economic opportunity is a justification for fans to be involved in the sport experience. The opportunity to wager on an event and gain some type of incentive, as a result, keeps the fan engaged with a team and the sport [57].

The beauty or art of the game and athletes' performance is another objective that would entice fans to an event [54,57]. People want to be perceived as if they belong and sincere group affiliation is a strong motivation for fans to attend events [54]. As fans follow a team, they have the ability to cheer and support a team as one unified body. Students and alumni of a college or university share this sense of belonging, as they each have one common trait among themselves: the institution. The piece to the original SFMS instrument is closely related to belonging, which is family. Fans may participate or attend sporting events with family [54,57].

In addition to the factors presented in the SFMS, other motivation factors are represented in various scales developed after the SFMS. Three factors were added to this study's instrument from the Motivation Scale for Sport Consumption (MSSC) developed by Trail and James [52]. These factors were knowledge, achievement and social. Knowledge, or increasing knowledge, exhibits that the individual is aware of sports and their favorite team, and keeps track of statistics and win-loss records of the team. The achievement factor pertains to how the individual feels when their team is winning or losing. For example, when the team has a successful season or wins a big game, the individual feels the same sense of achievement as the actual players and members of the team [52]. Lastly, social can be related to Wann's [54] group affiliation and family. However, it is particular considering it is referring to the individual being a fan and interacting with other fans during the game.

Wolfson, Wakelin, \& Lewis [58] found there are both motives and restraints for fan support, or lack thereof, of a sports team. The motives were self-esteem, group identity, tension reduction, intellectual pursuit, and social interaction. The restraints were financial costs, embarrassment, time, disappointment, and even anxiety [58]. Snelgrove et al. [48] indicates the higher the fan's motivation, the more likely it is that a fan will attend and consume sport events and entertainment. Social class can also impact who attends sporting events in relation to financial costs [15]. The cost of game attendance combined with concessions and souvenirs can quickly accumulate, especially when a family is in attendance. Additional costs are incurred for travel, lodging, food, and other amenities if a person must travel to another city, region or state to attend the event. Furthermore, having these amenities in close proximity is influential since fan motivation to travel has been found to be inhibited by an event location isolated from other attractions [26]. 
Likewise, demographics-gender, age, income-influence fan motivation and the desire to travel to college sporting events. Snelgrove, et al. [48] found gender roles could have an effect on fan motivation and attendance, in that females may not be as motivated to attend a game and would, therefore, need additional motivating factors to attend. Sports are often viewed as more masculine, and females may feel discouraged and choose not to attend the sporting event. Further, people are less likely to consume sport as they age, but are more likely to participate in other tourism activities such as the arts [48]. Finally, a higher discretionary income allows fans to participate in activities that someone with less income may not be able to engage in them. Fans want the best sport experience as possible and as their overall income and discretionary income increases, fans are more likely to be motivated to purchase tickets, travel to and attend a sporting event.

Overlapping with several factors from the sport motivation scales (SFMS and MSSC), Beerli and Martin's [5] study on destination image as a perception and feeling toward a destination or location, included several of the same motivation factors. In essence, sports fans would need a reason-playing the team from that school-to travel to the location. In particular, escape, social and entertainment were represented in the factors presented in Beerli and Martin's [5] study on destination image. Participants were asked to think about their travel experiences and use a 7-point rating scale to determine how each statement best described them. These 13 statements were derived from the factors listed in Beerli and Martin's [5] study on destination image.

Subsequent investigations further validated the SFMS instrument [55,57]. In addition to these validation studies, research conducted on subsections of the instrument, and motivations were validated by Wann, Lane, Duncan \& Goodson [56] with studies of the family and motivations and Wann \& Ensor [55] with observation at the economic subsection of the SFMS.

\section{Destination Image \\ Destination image fit}

The destination image of the event site is an important component of sport tourism, created by a Destination Marketing Organization (DMO). Therefore, it is crucial for sporting event planners to evaluate the destination. When assessing the site, event planners must consider if the destination is suitable in terms of the destination image and attractiveness, and if there is a destination image fit with the sport event and fans.

Since sporting events are a means to attract fans as tourists to a destination area, an allinclusive branding and marketing of the destination's key attractions and hospitality suppliers are fundamental [17]. DMOs are generally responsible for marketing the destination image to event/meeting planners and tourists, nationally and internationally. This is accomplished through cultivating relationships, coordinating services, and sharing information with the stakeholders (planners, tourists, government, community, and industry suppliers). With regards to sporting events, the DMO will work with local venues, public officials, and event planners to synchronize all the elements needed to amalgamate the destination brand image with the sports events [20].

Integrating the destination brand image with the sports events' requirements may necessitate that the attractiveness of a destination is changed or enhanced when a sporting event is located within the city or region. Funds provided from state sporting event incentives, grants, tax credits, or public subsidies, can be utilized by the DMOs and stakeholders on revitalizing areas that would further generate interest and attractiveness for sport tourists. Opportunities 
may additionally occur that facilitate appropriate local economic development or infrastructure changes necessary to accommodate the sport events that integrates with the destination image [20].

However, depending upon the event, the location may or may not be restricted to certain destination areas. The destination image can be a significant determinant when a planner has the option of choosing a different destination venue when looking at larger sporting events that are not site restrictive [20,41,34]. College bowl games are typically scheduled in December and January of each year, and a trip to a bowl game in a warmer climate could increase the attractiveness of the event location. This could persuade a fan to travel to the destination to see their favorite team play, who might not otherwise have visited this location. Destination image could play a key role in the fan satisfaction of a new venue, and revisit intentions. This is applicable in understanding the conference realignment process as many fans have the opportunity to travel to a city or area they may never have any intention of visiting until their favorite team was scheduled to compete there.

\section{Destination image travel motivation}

According to Baloglu and McCleary [3], destination image may be a determining intention factor for travelers. Kaplanidou and Vogt's [30]study focused on the perception of the destination image when associated with a sport event and the consumer's behavior that ensues. While a brand image is perceived as composed of attitudes, attributes, benefits and costs [31], destination image perception differs in terms of cognitive, emotion, and mental processes [3]. The branded destination image is used to establish a belief, idea, or impression of the area. Generally comprised of pictures, text, and other items, it is reflective of a destination area [14,22]. Chon [8] indicates that the destination image affects tourists' perception of the host destination, the intent to visit, and the level of satisfaction with the travel experience. It is critical that tourists see the location as an attractable destination. Beerli and Martin [5] indicated that one's perception of the destination and motivation to travel to an away venue is influenced by the sport fan's determinants (needs, motivations, personal factors, knowledge, and partialities) in addition to the branded destination image.

\section{Theory of Planned Behaviour}

Ajzen's [2] theory of planned behavior (TPB) sets the framework for this case study. Ajzen [2][3] identified three unique areas of behavior intent: attitudes, subjective norms and perceived behavioral control (PCB). TPB was utilized for this study to explain the motivations (attitudes, subjective norms) behind the decision to follow a particular sports team and then travel (subjective norms, perceived behavioral control) to away games. Cunningham \& Kwon [16] suggest "attitudes and subjective norms predict a person's intention to participate in an activity" (p. 129). Taylor and Todd [50] also propose that subjective norms and attitude play a role in the behavioral decisions of individuals. Bamberg, Ajzen and Schmidt [4] stated that the "perception of behavioral control leads to the formation of a behavioral intention" (p. 176).

Attitude is further described as to the positive or negative way in which a person views a particular behavior [2]. Conner and Armitage [12] discuss attitude as a person's observed beliefs, which might demonstrate potential results or behavior. For example, if someone believes that a favorable outcome will occur, then the attitude presented will be positive versus negative [16]. Attitude could also be described as a cost-benefit to the person [35]. One might look at a particular action (cost) associated with the likely outcome (benefit) and make a decision as to whether it is beneficial to perform the action or not. An example might be for the fan to travel or not to an away football game. If the team is favored to win, the individual might be more likely to travel to the new destination. 
Conversely, subjective norms refer to societal expectations to either participate or not in a given event [2, 3, 32]. Conner and Armitage [12] describe subjective norm as a "function of normative beliefs, which represent perceptions of specific significant others' preferences about whether one should or should not engage in the behaviour" (p. 1431). An individual is more likely to implement a behavior when the intent and societal norms are higher and more promising $[2,36,35]$. An individual member of a group of friends might feel pressured to incur the additional expenses (i.e., hotel, gas, food) of traveling to an away game in order to feel connected with one's personal group and the overall team affiliation.

The last piece of the framework for TPB is the idea of perceived behavioral control (PBC) or the supposed "ease or difficulty of performing the behavior" $[2,12,16]$. This could include access to resources or occasions needed for an individual to execute the behavior. The easier one believes that a behavior can be performed, the idea of PBC increases [12]. The PBC portion of TPB was added to explain incidences where an individual does not have full control over the situation [50]. Two components of PBC are identified: facilitating conditions and self-efficacy. The first, facilitating conditions, explains the readiness of resources needed to participate. Selfefficacy, the second component, is the confidence an individual has in him/herself to do the activity or behavior [50].

\section{Participants}

\section{METHOD AND PROCEDURE}

The participants for this case study were self-identified followers of Texas A\&M University athletics. They are users of the online message board, TexAgs, where they stay current on information regarding Texas A\&M University and its athletics program. Each participant was able to self-select for involvement in the study by clicking on the questionnaire link located in a thread on football related forums. The survey was available for a two-week period and a total of 646 surveys were collected. The population was representative of previous message board research in that the majority of respondents were male $(60.4 \%, \mathrm{~N}=485)$, married $(43.3 \%, \mathrm{~N}=$ $348)$, possess a bachelor's degree or higher $(61.7 \%, \mathrm{~N}=496)$ and have a household income of $\$ 75,000$ or higher $(45.3 \%, \mathrm{~N}=363)[9,22,44]$.

\section{Instrument}

The questionnaire consisted of three sections: (1) motivation, (2) destination image, and (3) demographics. The motivation section consisted of 33 survey questions covering the categories of the motive types. The instrument for the current study was comprised of items from established motivation scales. Each item within the questionnaire was modified to fit a college football fan population and wording was updated to mirror current trends in sports' terms and definitions. This case study was based on the 23-item scale, Sport Fan Motivation Scale (SFMS), developed by Wann [54] to study the fans of sporting events with additional motivations added from the MSSC and SII scales. The rating scale was anchored by $1=$ does not describe me at all to 7 = this describes me completely.

Destination image was measured using 15 items from Beerli and Martin's [5] study on factors that influenced pre-visit intentions and motivations for tourists. The items were anchored by 1 = strongly disagree to 7 = strongly agree. The wording was modified to fit the target audience of a college football fan. Destination image was utilized as a single factor in order to determine a correlation between (1) motivations to consume sport and (2) visit a new destination.

SPSS 21.0 was utilized to analyze the data. Descriptive-statistics analysis was conducted to examine the overall sample and understand the demographics of the sample population. 


\section{Data Collection}

Many sport-related studies have used fan message boards as a tool to locate groups that are concentrated into a dedicated area $[9,32]$. Other studies have looked at the motivations behind fans using message boards [24,44]. They serve as a hub for fans to discuss current events related to the respective athletics teams with other like-minded fans.

TexAgs is focused primarily on Texas A\&M University athletics and has many forums related to various teams and topics. Users have the option of becoming a member with a free account and limited access or may pay a yearly subscription to receive premium content on Texas A\&M University athletics. Latest numbers show nearly 600,000 unique monthly visitors between the online and mobile website with 45 million monthly page views [51].

The importance of using TexAgs for this sample was to find a subset of highly identified fans on a widely recognized medium. The questionnaire was distributed to college football fans via TexAgs for a two-week period of time. This period was chosen to follow the conclusion of the 2013-14 college football season.

A board moderator was contacted and assisted in the distribution of the questionnaire link by using a feature common to message boards, where a post is pinned to the top of each forum. This allows the thread to be more visible whenever a user enters the forum, thereby increasing the overall number of people viewing the questionnaire link. The post was shared on two sport forums within the website: 'Billy Luicci's TexAgs Premium' subscription board and the 'A\&M Football' free board.

\section{Data Analysis}

To determine the motivations for this particular subset of college football fans, an exploratory factor analysis (EFA) with varimax rotation with Kaiser normalization was conducted. Motivations have been well established for those that are sports fans as well as those that travel. Costello and Osborne [13] indicate an EFA can be used to explore motivations in addition to the development of an instrument. Likewise, Riaz, Rambli, Salleh and Mushtaq [43] utilized EFA in their study on motivations and perceptions. An EFA was chosen for the analysis in this case study in order to understand the highest motivations specific to this particular population as well as to create a common platform for all motivation instruments (i.e., SFMS, MSSC) used. The orthogonal rotation-varimax-allowed for the well-defined identification of each motivational factor [45].

Based on the criteria from Hair, Black, Babin, and Tatham [23] items with eigenvalues of 1.0 or higher were selected and the associated factors were identified. Additionally, Kaiser [29] stated that " eigenvalues greater than one of the observed correlation matrix led to a number of factors corresponding almost invariably" (p. 145) also contributed to the determination of the factors retained. Furthermore, a screen test was analyzed to establish the natural break in the curve. Nine motivation dimensions had eigenvalues that met the stated criteria of the 13 that were included in the questionnaire. Once the nine dimensions were identified, individual components of each motivation were combined and means were calculated to test correlations with the destination image dimension.

\section{RESULTS}

The case study began with a total of 13 dimensions to examine the motivations of why people attend away college football games. An exploratory factor analysis identified nine factors accounting for $72.93 \%$ of the variance (see Table I). The nine factors identified were: (a) achievement, (b) economic, (c) escape, (d) knowledge, (e) group affiliation, (f) social, (g) 
aesthetic, (h) eustress and (i) family. The participants in this study expressed the importance of how achievement and their involvement with the Texas A\&M football team are related. Participants indicated that achievement, the team's success, is important, accounting for $23.46 \%$ of variance. Not only are the participants experiencing the sense of achievement for the team, but for themselves as well.

Table I

Exploratory Factor Analysis of Motivations

\begin{tabular}{lcc}
\hline Factor & Eigen-value & Variance explained \\
\hline Achievement & 7.508 & 23.461 \\
Economic & 4.030 & 12.594 \\
Escape & 2.909 & 9.089 \\
Knowledge & 2.169 & 6.779 \\
Group Affiliation & 1.777 & 5.552 \\
Social & 1.442 & 4.505 \\
Aesthetic & 1.313 & 4.103 \\
Eustress & 1.097 & 3.428 \\
Family & 1.094 & 3.418 \\
& & \\
Total Variance Extracted (\%) & & 72.93 \\
\hline
\end{tabular}

The means for the nine motivation factors were calculated and all fell above the midpoint of the scale with the exception of economic (see Table II). The questions under the economic factor asked about the participants gambling and betting activity in relation to college sports, specifically Texas A\&M football $(M=1.54, \mathrm{SD}=1.19)$. All other factors were "neutral" to "very descriptive of me" categories with eustress being the factor rated highest on the scale $(\mathrm{M}=$ $6.23, S D=0.80)$. Knowledge $(M=5.98, S D=1.14)$, aesthetic $(M=5.48, S D=1.39)$, achievement $(M=5.28, S D=1.31)$, social $(M=5.04, S D=1.42)$ and group affiliation $(M=4.92, S D=1.07)$ were well above "neutral" in the motivations for sport consumption. College football is very competitive within the state of Texas as there are several other Division I football programs within the state. Texans are known for their pride in their state and anything they support. The fans of Texas A\&M have felt a great sense of pride in the institution and athletic programs with the move to the SEC.

Table II

Relative Rank and Reliability

\begin{tabular}{lccc}
\hline Factor & Mean & S.D. & Cronbach's $\alpha$ \\
\hline Eustress & 6.2267 & 0.80112 & 0.659 \\
Knowledge & 5.9757 & 1.13825 & 0.857 \\
Aesthetic & 5.4792 & 1.39161 & 0.748 \\
Achievement & 5.2830 & 1.31219 & 0.830 \\
Social & 5.0410 & 1.42083 & 0.860 \\
Group Affiliation & 4.9216 & 1.07338 & 0.711 \\
Destination Image & 4.6961 & 1.01834 & 0.872 \\
Family & 3.8401 & 1.86386 & 0.808 \\
Escape & 3.1523 & 1.79194 & 0.930 \\
Economic & 1.5362 & 1.18753 & 0.930 \\
\hline
\end{tabular}

Factors: $1=$ not at all descriptive of me, 7 = very descriptive of me;

Destination image: 1 = strongly disagree, 7 = strongly agree 
In addition to the identified factors, another area of the investigation examined destination image. Destination image was examined to determine if a relationship existed with the previously mentioned motivation factors for sport consumption. It was discovered that destination image was an important consideration for travel to away games $(M=4.69$, $\mathrm{SD}=1.02)$. A correlation was conducted with the nine motivation factors and destination image to determine if a relationship existed between the identified motivation factors and destination image (see Table III). Destination image showed a significant positive correlation with all factors except economic which was negatively correlated. The different factors were significantly correlated, but not distinct from one another. This may not translate into additional tourism dollars for the local community. College football games are typically on Saturdays and away game travel could be limited to the sporting event only since many people work and only have weekend days for travel. 
Table III

Correlation Table

\begin{tabular}{|c|c|c|c|c|c|c|c|c|c|c|c|}
\hline Factor & & Achievement & Economic & Escape & Knowledge & $\begin{array}{c}\text { Group } \\
\text { Affiliation }\end{array}$ & Social & Aesthetic & Eustress & Family & $\begin{array}{l}\text { Destination } \\
\text { Image }\end{array}$ \\
\hline \multirow{3}{*}{ Achievement } & $\begin{array}{c}\text { Pearson } \\
\text { Correlation }\end{array}$ & 1 & $.107^{* *}$ & $.268^{* *}$ & $.228^{* *}$ & $.384^{* *}$ & $.194^{* *}$ & $.152^{* *}$ & $.615^{* *}$ & $.152^{* *}$ & $.377^{*}$ \\
\hline & $\begin{array}{c}\text { Sig. } \\
\text { (2-tailed) }\end{array}$ & & 0.007 & 0 & 0 & 0 & 0 & 0 & 0 & 0 & 0 \\
\hline & $\mathrm{N}$ & & 649 & 649 & 562 & 650 & 614 & 648 & 650 & 591 & 192 \\
\hline \multirow{3}{*}{ Economic } & $\begin{array}{c}\text { Pearson } \\
\text { Correlation }\end{array}$ & & 1 & $.178^{* *}$ & $-.125^{* *}$ & -0.015 & -0.054 & $-.155^{* *}$ & $-.128 * *$ & -0.054 & -0.019 \\
\hline & $\begin{array}{c}\text { Sig. } \\
\text { (2-tailed) }\end{array}$ & & & 0 & 0.003 & 0.706 & 0.182 & 0 & 0.001 & 0.189 & 0.796 \\
\hline & $\mathrm{N}$ & & & 650 & 562 & 649 & 614 & 648 & 649 & 591 & 192 \\
\hline \multirow{3}{*}{ Escape } & $\begin{array}{c}\text { Pearson } \\
\text { Correlation }\end{array}$ & & & 1 & 0.032 & $.215^{* *}$ & $.157^{* *}$ & $.077^{*}$ & $.086^{*}$ & $.180^{* *}$ & $.300^{* *}$ \\
\hline & $\begin{array}{c}\text { Sig. } \\
(2 \text {-tailed })\end{array}$ & & & & 0.448 & 0 & 0 & 0.049 & 0.028 & 0 & 0 \\
\hline & $\mathrm{N}$ & & & & 562 & 649 & 614 & 648 & 649 & 591 & 192 \\
\hline \multirow{3}{*}{ Knowledge } & $\begin{array}{c}\text { Pearson } \\
\text { Correlation }\end{array}$ & & & & 1 & $.451^{* *}$ & $.354^{* *}$ & $.443^{* *}$ & $.451^{* *}$ & $.221^{* *}$ & $.469 * *$ \\
\hline & $\begin{array}{c}\text { Sig. } \\
(2 \text {-tailed })\end{array}$ & & & & & 0 & 0 & 0 & 0 & 0 & 0 \\
\hline & $\mathrm{N}$ & & & & & 562 & 562 & 561 & 562 & 560 & 192 \\
\hline \multirow{3}{*}{$\begin{array}{c}\text { Group } \\
\text { Affiliation }\end{array}$} & $\begin{array}{c}\text { Pearson } \\
\text { Correlation }\end{array}$ & & & & & 1 & $.630^{* *}$ & $.609^{* *}$ & $.614^{* *}$ & $.282^{* *}$ & $.463^{* *}$ \\
\hline & $\begin{array}{c}\text { Sig. } \\
\text { (2-tailed) }\end{array}$ & & & & & & 0 & 0 & 0 & 0 & 0 \\
\hline & $\mathrm{N}$ & & & & & & 614 & 648 & 650 & 591 & 192 \\
\hline \multirow{3}{*}{ Social } & $\begin{array}{c}\text { Pearson } \\
\text { Correlation }\end{array}$ & & & & & & 1 & $.326^{* *}$ & $.345^{* *}$ & $.324^{* *}$ & $.257^{* *}$ \\
\hline & $\begin{array}{c}\text { Sig. } \\
(2 \text {-tailed })\end{array}$ & & & & & & & 0 & 0 & 0 & 0 \\
\hline & $\mathrm{N}$ & & & & & & & 613 & 614 & 591 & 192 \\
\hline \multirow{3}{*}{ Aesthetic } & $\begin{array}{c}\text { Pearson } \\
\text { Correlation }\end{array}$ & & & & & & & 1 & $.452^{* *}$ & $.184^{* *}$ & $.319^{* *}$ \\
\hline & $\begin{array}{c}\text { Sig. } \\
(2 \text {-tailed })\end{array}$ & & & & & & & & 0 & 0 & 0 \\
\hline & $\mathrm{N}$ & & & & & & & & 648 & 590 & 192 \\
\hline \multirow{3}{*}{ Eustress } & $\begin{array}{c}\text { Pearson } \\
\text { Correlation }\end{array}$ & & & & & & & & 1 & $.197^{* *}$ & $.318^{* *}$ \\
\hline & $\begin{array}{c}\text { Sig. } \\
\text { (2-tailed) }\end{array}$ & & & & & & & & & 0 & 0 \\
\hline & $\mathrm{N}$ & & & & & & & & & 591 & 192 \\
\hline \multirow{3}{*}{ Family } & $\begin{array}{c}\text { Pearson } \\
\text { Correlation }\end{array}$ & & & & & & & & & 1 & $.192^{* *}$ \\
\hline & $\begin{array}{c}\text { Sig. } \\
\text { (2-tailed) }\end{array}$ & & & & & & & & & & 0.008 \\
\hline & $\mathrm{N}$ & & & & & & & & & & 192 \\
\hline \multirow{3}{*}{$\begin{array}{l}\text { Destination } \\
\text { Image }\end{array}$} & $\begin{array}{c}\text { Pearson } \\
\text { Correlation }\end{array}$ & & & & & & & & & & 1 \\
\hline & $\begin{array}{c}\text { Sig. } \\
(2 \text {-tailed })\end{array}$ & & & & & & & & & & \\
\hline & $\mathrm{N}$ & & & & & & & & & & 192 \\
\hline
\end{tabular}

**, Correlation is significant at the 0.01 level (2-tailed).

*, Correlation is significant at the 0.05 level (2-tailed).

\section{DISCUSSION}

Utilizing the theory of planned behavior (attitudes, subjective norms, and perceived behavioral control), we found that a fan's intent to travel to away games and a person's likelihood to be 
influenced to engage in this behavior was consistent. A focus on the fans not as individuals, but also as a group should be made prominent in any marketing plans. Fans are driven by group affiliation, social, and family factors, among others. College athletics departments should utilize promotions or discounts that are geared toward group travel, often done using travel packages and VIP experiences. Appealing to families would also be another step to increase the likelihood of travel, to not just home games, but for away trips that can be used as a time for vacation.

Often fans choose their away game experience as the family vacation for the year. One opportunity for both the university and local tourism organizations to capitalize would be to market the athletic stadium as a tourist destination for more than just the game. For example, stadium tours of historic college football stadiums or new facilities on non-game days would entice fans to extend the stay. The typical fan may also not be aware of additional attractions available at the away game location.

Currently, few if any, literature reviews, establish a relationship that exists between the universities and local DMOs for sports travel and marketing. These travel and tourism entities could partner with the university and athletic departments to offer weekend or extended packages for those traveling to away games. Another possible way to share local tourism options is to develop and circulate emails to those who have purchased tickets for the opposing team. This would give sport fans coming to the area an opportunity to review additional sightseeing options and entice the visitor to spend an extra night in the area, establishing the want for a future return trip.

Regardless of game attendance, sport fan individuals achieve the social, family and achievement aspects of motivations of supporting their teams. However, many of the motivations expressed by the participants in this case study (i.e., escape, family, social) can be experienced during the game day, especially the away game event. Both destination image and potential vacation experiences play a fundamental role in one's perception as to whether the location offers amenities that not only fulfills the intended destination image, but also the fan's recognition of being satisfied at the location. Through strategic destination brand development, DMOs and industry suppliers can further enhance the satisfaction received from attending the game at a new location, therefore increasing the fans' commitment to the team.

The primary goal in this case study was to identify what motivations are present in the Texas A\&M football fan population to attend away games. The recent move to the SEC has created an increased amount of publicity within the media, the state of Texas and within the SEC. The SEC is not only known for great tailgates and passionate fans, but also multi-million dollar budgets spent on athletics [11]. The large number of factors revealed in this case study shows that not only are Texas A\&M fans passionate about their college football team, but many of the factors explain why they travel to away games. Three of the factors present-group affiliation, social and family-explain the togetherness of being a fan and participating in college football activities, including tailgating and traveling to away football games to support the team. Economic, or wagering as used in this study, was not an identifying factor of the participants in this study. Participants did not feel that gambling described themselves as sports fans. Furthermore, college football fans are aware of their team's successes and failures, which is evident within both knowledge and achievement. Numerous websites are riddled with statistics on each player, game, team and season for individual football teams. Related to these are escape and eustress. Fans escape from everyday worries and life by engaging in sports, particularly college football, by reading sports news and closely following their team. Eustress, or the positive stress, describes the avid sports fan where one is caught up in the game and the 
success of the moment and the team. Overall, the motivation factors revealed in this case study show the passion and importance of college football and desire to follow their team, not only at home and online, but also to away games.

\section{CONCLUSION}

Prevailing conference alignments and new sporting venues dictate it is critical for DMO's, destination stakeholders, and sport event planners to work jointly to strategically position the events. Understanding the behavior and motivations of these football fans increases the likelihood of obtaining a good fit in terms of football fans and a suitable destination image. Destination images that offer the appropriate infrastructure, relevant hospitality industry suppliers, and gregariousness, not only motivate fans to escape reality and travel to the new venue, but also contrive the opportunity to increase fan attendance and consumer spending. These benefits can then improve destination in the long term by creating opportunities through renovations and building of new stadiums.

The theory of planned behavior and the football fans' motivation discovered in this research demonstrate that this can be successfully accomplished. The destination image must address the fan's TPB and motivations since there are additional costs-financially and psychologicallyassociated with traveling to a new destination venue for a football event. This image must contain references-pictures, text, videos, links-to achieve the perception of a favorable outcome for the fan and affirmative social expectations from family \& friends. Furthermore, the necessary information for the fans to locate resources-hotel, restaurants, attractions, and amenities-needed to participate in traveling away from home should be constructed in a way that one could navigate with ease and confidence. This can be performed through technology (websites), publication (brochures), and communication (e-mail and phone). Social media and emerging visual applications, such as Instagram, can also be utilized to highlight various parts of destination image to the masses.

Once football fans' TPB is addressed through a consistent destination image, the fan motivations researched in this case study-achievement, economic, escape, knowledge, group affiliation, social, aesthetic, eustress, and family-must also be taken into consideration. Our study demonstrates that as the fan's perception of the destination image develops positively, so does the motivations of the fan. With that said, it is crucial for the DMO to work with the venues, government and state officials, economic development agencies, and the community in order to get the right image for the destination. This will ensure that the fan will be motivated to attend the new event and develop affirmative attitudes toward the team, the venue, and the destination in order to increase their satisfaction and revisit intentions.

\section{References}

Ajzen, I. (1985). From Intentions to Actions: A Theory of Planned Behavior. In P. D. J. Kuhl \& D. J. Beckmann (Eds.), Action Control (pp. 11-39). Springer Berlin Heidelberg.

Ajzen, I. (1991). The theory of planned behaviour. Organizational Behaviour and Human Decision Processes, 50, 179-211.

Baloglu,E., \& McCleary, K. (1999). A model of destination image formation, Annals of Tourism Research, 26, (4), 868-897.

Bamberg, S., Ajzen, I., \& Schmidt, P. (2003). Choice of Travel Mode in the Theory of Planned Behavior: The Roles of Past Behavior, Habit, and Reasoned Action. Basic and Applied Social Psychology, 25(3), 175-187.

Beerli, A. \& Martin, J. D. (2004). Factors influencing destination image. Annals of Tourism Research, 31(3), 657-681.

Beerli, A. \& Martín, J.D. (2004) Tourists' characteristics and the perceived image of tourist destinations: A quantitative analysis - A case study of Lanzarote, Spain. Tourism Management, 25 (5), pp. 623-636. 
Chen, N. \& Funk, D. C. (2010). Exploring destination image, experience and revisit intention: A comparison of sport and non-sport tourist perceptions. Journal of Sport \& Tourism, 15(3), 239-259.

Chon, K., (1990). The role of destination image in tourism: An extension. Tourism Review, 47 (1), 2-8.

Clavio, Galen. (2008). Demographics and Usage Profiles of Users of College Sport Message Boards. International Journal of Sport Communication. 1. 10.1123/ijsc.1.4.434.

Clavio, G., \& Kian, E. M. (2010). Uses and gratifications of a retired female athlete's Twitter followers. International Journal of Sport Communication, 3, 485-500.

College Finances (2014). Retrieved from http://www.usatoday.com/sports/college/schools/finances/

Conner, M. \& Armitage, C. J. (1998). Extending the theory of planned behaviour: A review and avenues for further research. Journal of Applied Social Psychology, 28(15), 1429-1464.

Costello, A.B. \& Osborne, J. (2005). Best practices in exploratory factor analysis: four recommendations for getting the most from your analysis. Practical Assessment Research \& Evaluation, 10(7). Available online:

http://pareonline.net/getvn.asp?v=10\&n=7

Crompton, J. (1979). Motivations for pleasure vacation. Annals of Tourism Research 6(4), 408-424.

Cunningham, G. B. (2007) Diversity in sport organizations. Scottsdale, AR: Holcomb Hathaway.

Cunningham, G. B. \& Kwon, H. (2003). The theory of planned behaviour and intentions to attend a sport event. Sport Management Review, 6, 127-145.

Destination Marketing Association International. (2014, November). Engines of economic development. Retrieved December, 2015, from https://destinationsinternational.org/reports/destination-promotion-engine-economicdevelopment

Funk, D. C., Mahony, D. F., Nakazawa, M., \& Hirakawa, S. (2001). Development of the Sports Interest Inventory(SII): Implications for measuring unique consumer motives at sporting events. International Journal of Sports Marketing \& Sponsorship, 3.

Funk, D.C., Filo, K., Beaton, A., \& Pritchard, M. (2009). Measuring motives for sport event attendance: Bridging the academic-practitioner divide. Sport Marketing Quarterly, 18, 126-138.

Getz, D. (2008). Event tourism: Definition, evolution, and research. Tourism Management, 29, 403-428.

Global Trust in Advertising and Brand Management. (2012, April 10). Nielson Reports and Insights. Retrieved June 5, 2014, from http://www.nielsen.com/us/en/reports/2012/global-trust-in-advertising-and-brandmessages.html.

Gunn, C. (1972). Vacationscape. Bureau of Business Research, University of Texas, Austin, TX.

Hair, J. H., Jr., Black, W. C., Babin, B. J., \& Tatham, R. L. (2005). Multivariate data analysis. Upper Saddle River, NJ: Prentice Hall.

Hardin, R., Koo, G. Y., Ruihley, B., Dittmore, S. W., \& McGreevey, M. (2012). Motivation for consumption of collegiate athletics subscription web sites. International Journal of Sport Communication, 5(3), 368-383.

Hinch, T.D., \& Jackson, E.L. (2000). Leisure constraints research: Its value as a framework for understanding tourism seasonability. Current Issues in Tourism, 3(2), 87-106.

Hinch, T., Jackson, E.L., Hudson, S., \& Walker, G. (2005). Leisure constraint theory and sport tourism. Sport in Society: Cultures, Commerce, Media, Politics, 8(2), 142-163.

Hoye, R., \& Lillis, K. (2008). Travel motivations of Australian Football League fans: An exploratory study. Managing Leisure, 13(1), 13-22.

Kahle, L. R., Kambara, K. M., \& Rose, G. M. (1996). A functional model of fan attendance motivations for college football. Sport Marketing Quarterly, 5(4), 51-60.

Kaiser, H., 1960. The application of electronic computers to factor analysis. Educational and Psychological Measurement. 20, 141-151.

Kaplanidou, K. \& Vogt, C. (2007) The Interrelationship between sport event and destination image and sport tourists' behaviours, Journal of Sport \& Tourism, 12:(3-4), 183-206, DOI: 10.1080/14775080701736932.

Keller, K.L. (1993). Conceptualizing, measuring, and managing customer-based brand equity. Journal of Marketing, 57(January), 1-22. 
Kian, E. M., Clavio, G., Vincent, J., \& Shaw, S. D. (2011). Homophobic and sexist yet uncontested: Examining football fan postings on internet message boards. Journal of Homosexuality 58, 680-99.

Kogan, V., \& Greiser, S. (2014). Conflicts of College Conference Realignment: Pursuing Revenue, Preserving Tradition, and Assessing the Future (Working Paper No. 14-073). Retrieved from Harvard Business School website: http://www.hbs.edu/faculty/Publication\%20Files/14-073_ea70abf6-d99c-4529-96b2e8bef262a4e6.pdf

Lepp, A., Gibson, H., \& Lane, C. (2011). Image and perceived risk: A study of Uganda and its official tourism website. Tourism Management, 32(3), 675-684.

McCullough, B. P. (2013). Identifying the influences on sport spectator recycling behaviours using the theory of planned behaviour. International Journal of Sport Management \& Marketing, 14(1-4), 146-168.

McCullough, B. P., \& Cunningham, G. B. (2011). Recycling intentions among youth baseball spectators. International Journal of Sport Management \& Marketing, 10(1/2), 104-120.

National Collegiate Athletic Association. (2016). Retrieved November, 2015, from http://fs.ncaa.org/Docs/stats/football_records/Attendance/2016.pdf

Neale, L. \& Funk, D. (2005). Fan motivation and loyalty: Extending the Sport Interest Inventory (SII) to the Australian Football League. ANZMAC 2005 Conference: Broadening the Boundaries. Fremantle, Western Australia.

Nielsen. (2012, April 10). Consumer trust in online, social, and mobile advertising grows. Retrieved December, 2015, from https://www.nielsen.com/us/en/insights/news/2012/consumer-trust-in-online-social-and-mobileadvertising-grows.html.

Olson, M. (2014, June 26). Stadium renovations rampant in Big 12. ESPN. Retrieved July 14, 2014, from http://espn.go.com/blog/ncfnation/post/_/id/95716/stadium-renovations-rampant-in-big-12

Pennington-Gray, L., Gibson, H., \& Lane, C. (2011, November 28). Study: What college sports fans do when attending a game?. Study: College Sport Fans and Their Favorite Activities. Retrieved June 20, 2014, from http://www.tourism-review.com/travel-tourism-magazine-study-college-sport-fans-and-their-favorite-activities$\underline{\operatorname{article} 1686}$

Preuss, H., \& Solberg, H.A. (2006). Attracting major sporting events: The role of local residents. European Sport Management Quarterly, 6, 391-411.

Riaz, S., Rambli, D. R. A., Salleh, R. \& Mushtaq, A. (2011). Exploratory factor analysis (EFA) to examine learner's aesthetic perceptions and motivation through their aesthetic-emotions in informal visual environments. Information Technology Journal, 10, 268-1284.

Ruihley, B.J. \& Hardin, R.L. (2011). Message boards and the fantasy sport experience. International Journal of Sport Communication, 4(2), 233-252.

Schmidt, R., \& Watanabe, Y. (2001). Motivation, learning strategies, and pedagogical preferences. In Z. Dörnyei and R. Schmidt (Eds.), Motivation and Second Language Acquisition (pp. 313-359). Honolulu: University of Hawai'i, National Foreign Language Resource Center.

Silver, A. (2011, September 19). The Geography of College Football Fans (and Realignment Chaos). The Quad The Geography of College Football Fans and Realignment Chaos Comments. Retrieved July 10, 2014, from http://thequad.blogs.nytimes.com/2011/09/19/the-geography-of-college-football-fans-and-realignmentchaos $/$ ? _php=true\&_type=blogs\&_r $=0$

Smith, A.C.T., \& Stewart, B. (2007). The traveling fan: Understanding the mechanisms of sports fan consumption in a sport tourism setting. Journal of Sport and Tourism, 12, 155- 181.

Snelgrove, R., Taks, M., Chalip, L., \& Green, B. C. (2008). How visitors and locals at a sport event differ in motives and identity. Journal of Sport \& Tourism, 13(3), 165-180.

Stadium Journey. (2014). Retrieved July 5, 2014 from http://www.stadiumjourney.com/.

Taylor, S. \& Todd, P. (1995) Decomposition and Crossover Effects in the Theory of Planned Behavior: A Study of Consumer Adoption Intentions. International Journal of Research in Marketing, 12, 137-155.

TexAgs.com Media Kit. (2014, January 1). TexAgs.com. Retrieved June 3, 2014, from http://texags.com/about/mediakit\#demographics

Trail, G. T. \& James, J. D. (2001). The motivation scale for sport consumption: Assessment of the scale's psychometric properties. Journal of Sport Behaviour, 24(1), 108-127. 
Trotter, J. (2014, June 25). Regents approve OU stadium renovation. ESPN. Retrieved July 14, 2014, from http://espn.go.com/blog/big12/post//id/85941/regents-approve-ou-stadium-renovation

Wann, D. L. (1995). Preliminary validation of the sport fan motivation scale. Journal of Sport \& Social Issues, 19, 377-396.

Wann, D. L. \& Ensor, C. L. (1999). Further validation of the economic subscale of the sport fan motivation scale. Perceptual and Motor Skills, 88, 659-660.

Wann, D. L., Lane, T. M., Duncan, L. E., \& Goodson, S. L. (1998). Family status, preference for sport aggressiveness, and sport fan motivation. Perceptual and Motor Skills, 86, 1419-1422.

Wann, D. L., Schrader, M. P., \& Wilson, A. M. (1999). Sport fan motivation: Questionnaire validation, comparisons by sport, and relationship to athletic motivation. Journal of Sport Behaviour, 22, 114-139.

Wolfson, S., Wakelin, D., \& Lewis, M. (2005). Football supporters' perceptions of their role in the home advantage. Journal of Sport Sciences, 23(4), 365-374.

World Tourism Organization. (1993). Definitions Concerning Tourism Statistics. Retrieved February, 2012, from http://cf.cdn.unwto.org/sites/all/files/docpdf/glossaryenrev.pdf 